Bangladesh Journal of Anatomy July 2009, Vol. 7 No. 2 pp. 94-100

\title{
Morphological and Histological Study of The Pyramidal Lobe of The Thyroid Gland In Bangladeshi People - A Postmortem Study
}

\author{
Abu Sadat Mohammad Nurunnabi ${ }^{1}$, Abdul Alim², Sabiha Mahbub ${ }^{3}$, Segupta Kishwara ${ }^{4}$, \\ Manowara Begum ${ }^{5}$, Monira Khatun ${ }^{6}$, Shamim Ara ${ }^{7}$
}

\begin{abstract}
:
Background: The pyramidal lobe of the thyroid gland is an embryonic remnant of the caudal end of the thyroglossal tract. The pyramidal lobe is formed from normal thyroid tissue. A fibrous band, levator glandulae thyroideae, is found occasionally and extending upwards from the apex of the pyramidal lobe. As all thyroid diseases are found to be present in the pyramidal lobe, the study of the pyramidal lobe bears a great importance.

Study design: Cross-sectional descriptive type of study.

Place and period of study: Department of Anatomy, Dhaka Medical College, Dhaka from January to December 2008.

Materials: The present study was performed on 60 post mortem human thyroid gland (39 male and 21 female) collected from unclaimed dead bodies which were in the morgue under examination in the Department of Forensic Medicine, Dhaka Medical College, Dhaka.

Methods: The samples were divided into three age-groups including Group A (10-20 years), Group B (2150 years) \& Group C (>50 years) and the pyramidal lobes were studied both morphologically i.e. position, length, breadth, thickness, its association with levator glandulae thyroideae and histologically including presence of thyroid tissue, percentage proportion of parenchyma and stroma.

Results: The pyramidal lobe was found in 25 cases out of 60 (41.67\%) and situated more on the left side (56\%). The mean $\pm S D$ length of the pyramidal lobe of the thyroid gland was $10.83 \pm 0.75 \mathrm{~mm}$ in group $A$, $12.80 \pm 3.05 \mathrm{~mm}$ in group $B$ and $11.00 \pm 1.41 \mathrm{~mm}$ in group $C$. The mean $\pm S D$ breadth of the pyramidal lobe was $5.50 \pm 1.22 \mathrm{~mm}$ in group $A, 7.60 \pm 2.06 \mathrm{~mm}$ in group $B$ and $6.75 \pm 0.96 \mathrm{~mm}$ in group $C$. The mean $\pm S D$ thickness of the pyramidal lobe was $3.00 \pm 0.00 \mathrm{~mm}$ in group $A, 3.27 \pm 0.59 \mathrm{~mm}$ in group $B$ and $3.00 \pm 0.96$ $\mathrm{mm}$ in group C. The levator glandulae thyroideae was found in 12 cases out of 60 (20\%) and extended from the apex of the pyramidal lobe to the body of the hyoid bone. The proportion of the parenchyma increases with advancing age upto 50 years.
\end{abstract}

Key Words: morphology, histology, pyramidal lobe, thyroid gland

1. Medical Officer, Union Sub-centre, Shampur, Islampur, Jamalpur.

2. Anaesthesist, Upazilla Health Complex, Modhupur, Tangail.

3. Assistant Professor, Department of Anatomy, TMMC, Gazipur.

4. Assistant Professor (c.c.), Department of Anatomy, Dhaka Medical College, Dhaka.

5. Associate Professor (c.c.), Department of Anatomy, Dhaka Medical College, Dhaka.

6. Associate Professor, Department of Anatomy, Dhaka Medical College, Dhaka.

7. Professor and Head, Department of Anatomy, Dhaka Medical College, Dhaka.

Correspondence: Dr. Abu Sadat Mohammad Nurunnabi.

\section{Introduction:}

The thyroid gland is the largest endocrine gland in the human body ${ }^{1}$, which is highly vascular, brownish-red in colour, situated anteriorly in the lower part of the neck extending from the level of the $5^{\text {th }}$ cervical to the $1^{\text {st }}$ thoracic vertebrae, consists of two symmetrical lobes connected by an isthmus ${ }^{2}$. A conical pyramidal lobe often ascends upwards from the isthmus or adjacent part of the either of the lobes, more often from the left side ${ }^{3}$. The size of the pyramidal lobe varies from 'small' to 'large', 'huge' and 'enormous' ${ }^{4}$. It is 
a normal component of the thyroid gland, and not a congenital anomaly ${ }^{4}$ rather defined as an embryologic remnant of the caudal end of the thyroglossal tract ${ }^{5}$. A fibrous or fibromuscular band, the levator glandulae thyroideae, sometimes descends from the body of the hyoid bone to the isthmus or pyramidal lobe ${ }^{2}$. It may be considered as a fibrous or muscular replacement of the pyramidal lobe ${ }^{6}$.

The frequency of the pyramidal lobe is quoted in surgical and anatomical texts as varying from $43-80 \%$. Over the past years, cadaveric exploration reported its frequency ranging from $29-55 \%{ }^{7}$. The pyramidal lobe is formed from normal thyroid tissue. All the thyroid diseases are described in the pyramidal lobe also. After surgical removal of the thyroid gland, a residual thyroid tissue in the pyramidal lobe can be responsible for recurrence or complications of the disease, as in cancer or Graves' disease ${ }^{8}$. Therefore, the study of the pyramidal lobe has a great importance. Moreover, the knowledge about the fleshy slip of the levator glandulae thyroideae is also very important during neck surgery to avoid the iatrogenic injuries ${ }^{9}$.

\section{Materials and methods:}

Materials of the study:

A cross-sectional descriptive type of study was designed and done in the Department of Anatomy, Dhaka Medical College, Dhaka from January to December 2008, based on collection of 60 human thyroid glands from the unclaimed dead bodies that were under examination in the Department of Forensic Medicine, Dhaka Medical College, Dhaka from February 2008 to October 2008.

Grouping of the samples:

The samples were divided into three age-groups i.e. Group A (10 -20 years), Group B (21-50 years) \& Group C (>50 years) according to Brown, Al-Moussa and Beck (1986) ${ }^{10}$.
Table-I

Grouping of the sample of the present study $(n=60)$

\begin{tabular}{|c|c|c|c|}
\hline \multirow[t]{2}{*}{ Group } & \multirow{2}{*}{$\begin{array}{l}\text { Age limit } \\
\text { in years }\end{array}$} & \multicolumn{2}{|c|}{ Number of samples } \\
\hline & & Male & Female \\
\hline $\bar{A}$ & $10-20$ & 8 & 5 \\
\hline B & $21-50$ & 24 & 10 \\
\hline C & $>50$ & 7 & 6 \\
\hline
\end{tabular}

Procedure of morphological study:

The anterior aspect of the specimen consisting of pharynx, part of oesophagus, larynx, trachea, thyroid and parathyroid glands, major vessels of the neck was dissected. During dissection of the specimen, observation notes were taken about presence or absence of the pyramidal lobe. When present, its position was noted and its length from base to apex and breadth at the base were measured by a thread and then the thread was imposed on a measuring tape (in $\mathrm{mm}$ ). The levator glandulae thyroideae muscle was traced, if present. Then its cranio-caudal extension and its relation with the pyramidal lobe were also observed. After collection of the sample, pyramidal lobe of the thyroid gland was cut and put on a tray. The thickness was measured at its maximum position by pricking a pin through it and then by imposing it on a measuring tape (in $\mathrm{mm}$ ). To measure each parameter three readings were taken and the average result was noted down.

Procedure of histological study:

a) Preparation of the slide :

Tissue blocks of the pyramidal lobe were fixed in $10 \%$ formol saline in a plastic container. The tissues were washed in running tap water, dehydration was done with ascending grades of alcohol, cleared with xylene, infiltrated and embedded in paraffin. Paraffin blocks were cut at $5 \mathrm{~mm}$ thickness and were stained with routine Harris' Haematoxylin and Eosin $(\mathrm{H}$ \& E) stain.

b) Microscopic measurement :

The light compound microscope which was used for the microscopic measurement was OLYMPUS CHB, made in Tokyo, Japan and studied at low magnification (x10 objective x10 eyepiece). 
c) Estimation of proportion of parenchyma and stroma The parenchyma of the thyroid glands consists of the thyroid follicles including follicular epithelial cells, parafollicular cells and the colloid. The stromal part includes connective tissue and vessels. From each age group, 10 best prepared slides were taken.

The proportion of structural components of the thyroid gland was determined with the point counting technique described by Aherne and Dunnill (1966) ${ }^{11}$. Point counting Zeiss I integrating eyepiece was prepared in a transparent plastic sheet and was placed into the eyepiece. This eyepiece contains a point network of 25 points spaced at $70 \mathrm{~mm}$, arranged within a circle which is regarded as the counting field. Then the counting was done. The position of each point falling on any structural component was recorded for each field. Then the eyepiece was rotated $90^{\circ}$ keeping the field constant. Again the position of the each point was recorded. Thus 50 points were recorded for each field. Five such fields or 250 points were studied on each section. The total number of points fitting each component was summed up and expressed as a percentage of the total number of points fitting the structural component of thyroid glands. This percentage represents the proportion of parenchyma (glandular tissue) and stroma.

Statistical processing of data:

The data collected from the morphological and histological studies were processed and statistical analyses were done by unpaired Student's 't' test and one-way ANOVA test. All the statistical analyses were done by using the SPSS 11.0 version.

\section{Results:}

In the present study, the pyramidal lobe was found in 25 cases out of 60 (41.67\%). It was also observed that the pyramidal lobe was situated more on the left side (56\%) than on the right side (16\%), and a few were at the middle (28\%) of the isthmus of the thyroid gland (Table-II, Fig.-1).

The levator glandulae thyroideae was found in 12 cases out of 60 (20\%). In all cases, the levator glandulae thyroideae extended from the apex of the pyramidal lobe to the body of the hyoid bone (Table-III).

The mean $\pm S D$ length of the pyramidal lobe in male and female and in different age group are shown in Table-IV, Fig.-2).

The mean $\pm S D$ breadth of the pyramidal lobe in male and female and in different age group are shown in Table-IV, Fig.-3.

The mean $\pm S D$ thickness of the pyramidal lobe in male and female and in different age group are shown in Table-IV, Fig.-4.

The mean $\pm S D$ proportion of parenchyma and stroma of the pyramidal lobe of the thyroid gland in different age group is shown in Table-V, Fig.-5.

Table-II

Incidence of attachment of the pyramidal lobe with isthmus

\begin{tabular}{lcccc}
\hline Group Sex $(\mathrm{n})$ & \multicolumn{4}{c}{ Attachment } \\
\cline { 2 - 4 } & $\begin{array}{c}\text { Left side of the } \\
\text { isthmus }\end{array}$ & $\begin{array}{c}\text { Middle of the } \\
\text { isthmus }\end{array}$ & $\begin{array}{c}\text { Right side of the } \\
\text { isthmus }\end{array}$ & Absent \\
\hline A Male (8) & $3(5 \%)$ & $1(1.67 \%)$ & $1(1.67 \%)$ & $3(5 \%)$ \\
Female (5) & $1(1.67 \%)$ & 0 & 0 & $4(6.67 \%)$ \\
B Male (24) & $6(10 \%)$ & $3(5 \%)$ & $4(6.67 \%)$ & $11(18.33 \%)$ \\
Female (10) & $1(1.67 \%)$ & 0 & $1(1.67 \%)$ & $8(13.33 \%)$ \\
C Male (7) & $2(3.33 \%)$ & 0 & $1(1.67 \%)$ & $4(6.67 \%)$ \\
Female (6) & $1(1.67 \%)$ & 0 & 0 & $5(8.33 \%)$ \\
\hline
\end{tabular}


Table-III

Incidence of levator glandulae thyroideae

\begin{tabular}{lcc}
\hline Group / Sex (n) & Present & Absent \\
\hline A Male (8) & $3(5 \%)$ & $5(8.33 \%)$ \\
Female (5) & $1(1.67 \%)$ & $4(6.67 \%)$ \\
B Male (24) & $4(6.67 \%)$ & $20(33.33 \%)$ \\
Female (10) & $2(3.33 \%)$ & $8(13.33 \%)$ \\
C Male (7) & $1(1.67 \%)$ & $6(10 \%)$ \\
Female (6) & $1(1.67 \%)$ & $5(8.33 \%)$ \\
\hline
\end{tabular}

Table-IV

Length, breadth and thickness of pyramidal lobe of thyroid gland

\begin{tabular}{|c|c|c|c|}
\hline $\begin{array}{l}\text { Group/ } \\
\text { Sex } \\
\text { (n) } \\
\end{array}$ & $\begin{array}{c}\text { Length } \\
(\mathrm{mm}) \\
\text { Mean } \pm \text { SD }\end{array}$ & $\begin{array}{c}\text { Breadth } \\
(\mathrm{mm}) \\
\text { Mean } \pm \text { SD }\end{array}$ & $\begin{array}{c}\text { Thickness } \\
(\mathrm{mm}) \\
\text { Mean } \pm \text { SD }\end{array}$ \\
\hline \multicolumn{4}{|l|}{ Group A } \\
\hline $\begin{array}{l}\text { Male } \\
\text { (5) }\end{array}$ & $\begin{array}{r}10.80 \pm 0 \\
(10.00-12\end{array}$ & $\begin{array}{c}5.40 \pm 1.3 \\
(4.00-7.00)\end{array}$ & $\begin{array}{c}3.00 \pm 0.00 \\
(3.00-3.00)\end{array}$ \\
\hline $\begin{array}{l}\text { Female } \\
\text { (1) }\end{array}$ & 11.00 & 6.00 & 3.00 \\
\hline $\begin{array}{l}\text { value } \\
\text { roup B }\end{array}$ & $>0.5$ & $>0.50^{\mathrm{ns}}$ & \\
\hline $\begin{array}{l}\text { ale } \\
\text { 3) }\end{array}$ & $\begin{array}{l}13.00 \pm \\
(8.00-1\end{array}$ & $\begin{array}{c}7.77 \pm 2.17 \\
(5.00-12.00)\end{array}$ & $\begin{array}{l}3.38 \pm 0.51 \\
(3.00-4.00)\end{array}$ \\
\hline $\begin{array}{l}\text { Female } \\
(2)\end{array}$ & $\begin{array}{r}11.50 \pm \\
(10.00-1\end{array}$ & $\begin{array}{c}6.50 \pm 0.71 \\
(6.00-7.00)\end{array}$ & $\begin{array}{c}2.50 \pm 0.71 \\
(2.00-3.00)\end{array}$ \\
\hline $\begin{array}{l}\mathrm{P} \text { value } \\
\text { Group C }\end{array}$ & $>0.5$ & $>0.10^{\mathrm{ns}}$ & $<0.05^{*}$ \\
\hline ale & $\begin{array}{l}11.33= \\
(10.00\end{array}$ & $\begin{array}{l}7.00 \pm 1 \\
(6.00-8\end{array}$ & $\begin{array}{c}3.00 \pm 0.00 \\
(3.00-3.00)\end{array}$ \\
\hline $\begin{array}{l}\text { Female } \\
\text { (1) }\end{array}$ & 10.00 & 6.00 & 3.00 \\
\hline value & $>0.5$ & $>0.10^{\mathrm{ns}}$ & \\
\hline & $10.83=$ & $5.50 \pm 1.2$ & $3.00 \pm 0.00$ \\
\hline i) & 0 & $(4.00$ & $(3.00-3.00)$ \\
\hline & $12.80 \pm$ & $7.60 \pm 2.0$ & $3.27 \pm 0.59$ \\
\hline 5) & $00-$ & (5.00-12. & $(2.00-4.00)$ \\
\hline & $11.00 \pm 1$ & $6.75 \pm 0.9$ & $3.00 \pm 0.00$ \\
\hline 4) & 0.0 & (6.00-8. & $(3.00-3.00)$ \\
\hline & & P value & $P$ value \\
\hline VS & & $<0.05^{*}$ & $>0.10^{\mathrm{ns}}$ \\
\hline & $>0$ & $>0.10^{\mathrm{ns}}$ & $>0.5$ \\
\hline vs C & $>0.10^{\text {ns }}$ & $>0.10^{\mathrm{ns}}$ & $>0.10^{\mathrm{ns}}$ \\
\hline
\end{tabular}

Figures in parentheses indicate range. Comparison between sex done by unpaired Student's 't' test and between different age group by One way ANOVA (PostHoc), ns = not significant, ${ }^{*}=$ significant Group A : Age 10-20 years Group B : Age 21-50 years Group C : Age $>50$ years
Table-V

Proportion of parenchyma and stroma

\begin{tabular}{|c|c|c|}
\hline Group & $\begin{array}{c}\text { Parenchyma } \\
\text { (\%) }\end{array}$ & $\begin{array}{c}\text { Stroma } \\
(\%)\end{array}$ \\
\hline (n) & Mean $\pm S D$ & Mean $\pm S D$ \\
\hline$A$ & $61.08 \pm 1.25$ & $38.36 \pm 1.91$ \\
\hline (10) & (58.10-63.40) & $(36.60-40.50)$ \\
\hline B & $68.89 \pm 2.43$ & $32.07 \pm 2.35$ \\
\hline (10) & $(64.10-72.50)$ & $(30.10-38.30)$ \\
\hline C & $61.56 \pm 3.35$ & $38.42 \pm 3.06$ \\
\hline \multirow[t]{2}{*}{$(10)$} & $(58.50-64.20)$ & $(36.80-41.60)$ \\
\hline & $P$ value & $P$ value \\
\hline$A$ vs $B$ & $<0.001^{\star \star *}$ & $<0.01^{* *}$ \\
\hline A vs C & $>0.50^{\text {ns }}$ & $>0.50^{\text {ns }}$ \\
\hline B vs C & $<0.001^{\star \star \star}$ & $<0.01^{* *}$ \\
\hline
\end{tabular}

Figures in parentheses indicate range. Comparison between different age group by One way ANOVA (PostHoc), ns = not significant,

$\star * / * * *$ significant

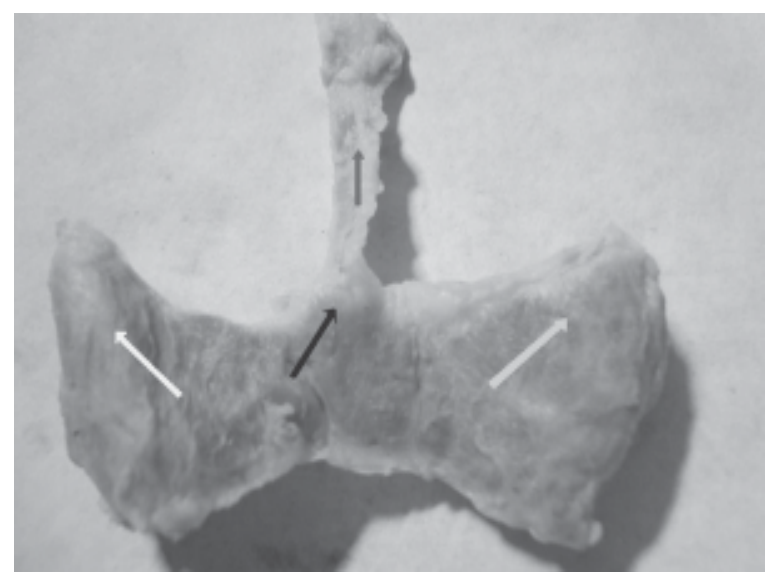

Fig.-1: Anterior view of the thyroid gland showing right lobe (white arrow), left lobe (white arrow), isthmus along with pyramidal lobe (black arrow) and levator glandulae thyroideae (black arrow). 


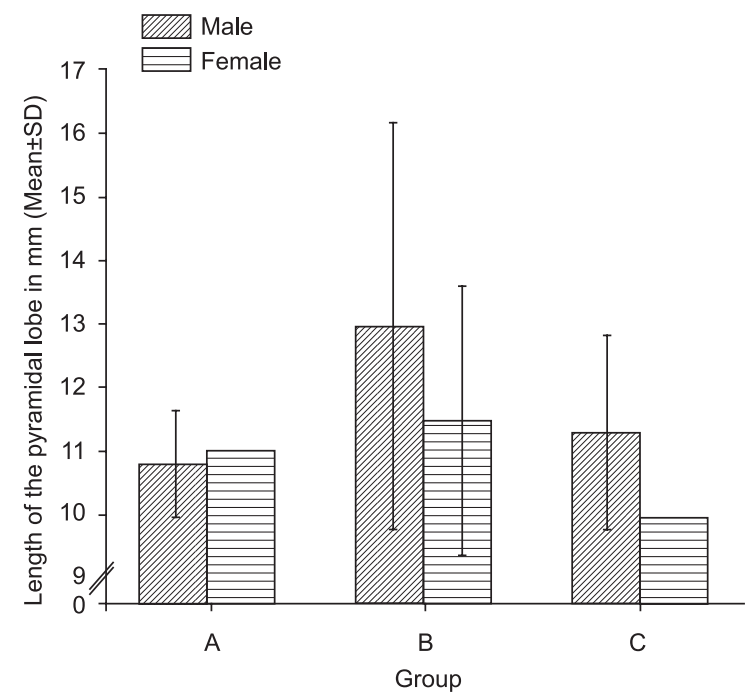

Fig.-2: Length of the pyramidal lobe of male and female in different age

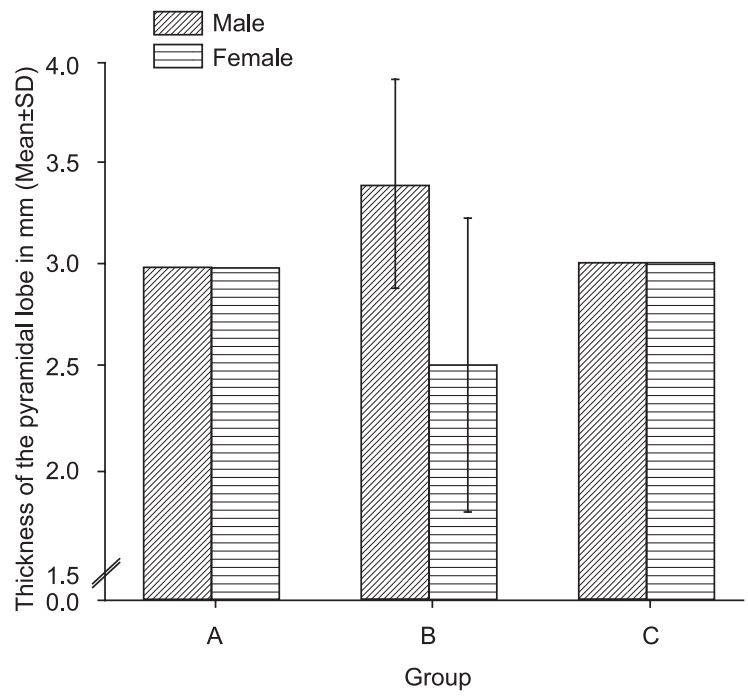

Fig.-4: Thickness of the pyramidal lobe of male and female in different age group.

\section{Discussion:}

Marshall $(1895)^{12}$ studied cadaveric specimens and found pyramidal lobe with levator glandulae thyroideae in multiple cases. Izenstark $(1968)^{13}$ studied 130 patients by using spark image and rectilinear scan and confirmed the presence of the pyramidal lobe in 39 cases (30\%), while another 7 cases were doubtful (5.38\%). Blumberg (1981) observed 17 cases preoperatively and 53 cases retrospectively who had undergone thyroid surgery

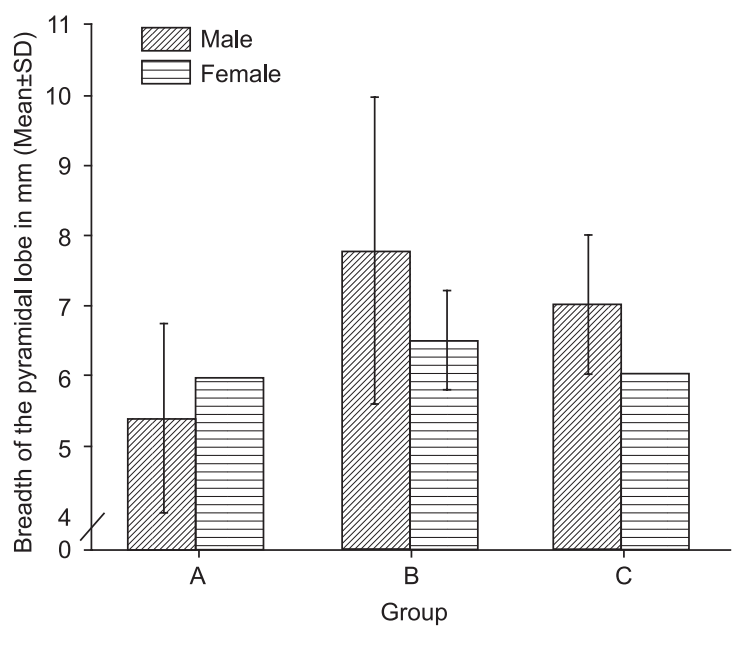

Fig.-3: Breadth of the pyramidal lobe of male and female in different age group.

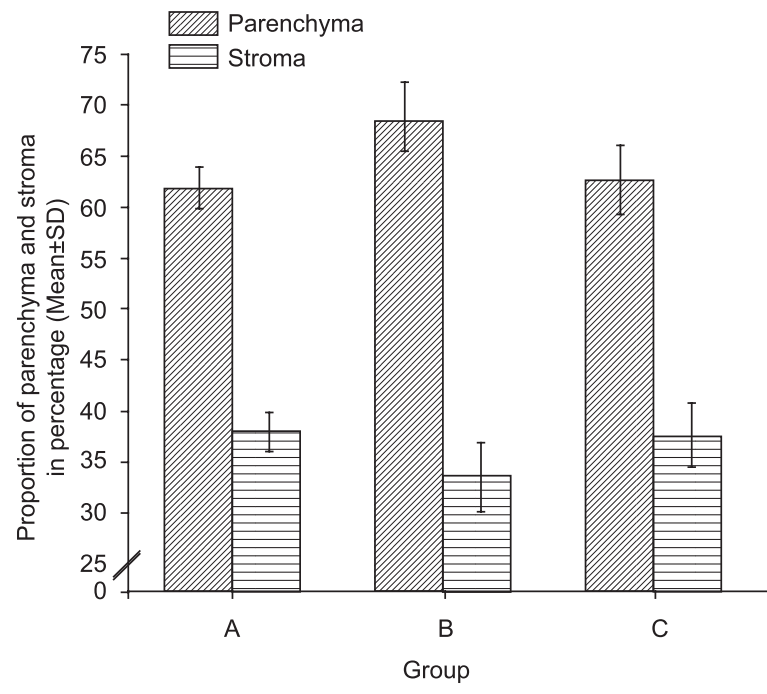

Fig.-5: Proportion of parenchyma and stroma of the pyramidal lobe in different age group.

and stated that $60 \%-65 \%$ cases had the pyramidal lobe and in most cases its location was at left side of the gland (left : right =13:1). Enayetullah $(1996)^{14}$ found the pyramidal lobe and the levator glandulae thyroideae in $50 \%$ and $32 \%$ of cases respectively. In most cases, the pyramidal lobe was found on the left side of the isthmus and associated with the levator glandulae thyroideae. Begum (2004) ${ }^{15}$ found pyramidal lobe in $26.7 \%$ (16 cases out of 60 ) and most were from the left side and levator glandulae 
thyroideae only in $15 \%$ of cases and all were originated from the pyramidal lobe. Sultana et al $(2008)^{16}$ observed that a half of the cases (30 out of $60)$ had pyramidal lobe where incidence was more in males (52.1\%) than that of females (41.7\%). In most cases, the pyramidal lobe was found on the left side of the isthmus (56.66\%). They also measured the length and breadth and found a range from 1.8 to $35 \mathrm{~mm}$ and from 1.3 to $19 \mathrm{~mm}$ respectively. Sultana et al (2009) ${ }^{17}$ found that the levator glandulae thyroideae was evident in $43.33 \%$ cases. They found the levator glandulae thyroideae in 26 cases out of 60 . Among those 22 (84.65\%) were associated with the pyramidal lobe, all extending from the apex of the pyramidal lobe to the hyoid bone. 4 were found to take origin from the isthmus, of which 2 were attached to the hyoid bone and other 2 with the corresponding oblique line of the thyroid cartilage above. In 1962, Wantabe and Suda observed the levator glandulae thyroideae in 6 cases out of 7 i.e. $85.71 \%$ (cited by Lehr in 1979) ${ }^{18}$, but Lehr himself studied 203 mixed racial cadavers and found this muscle only in 1 case (0.49\%). Enayetullah $(1996)^{14}$ observed this muscle in $32 \%$ of cases and most of them were associated with the pyramidal lobe. Ranade et al (2008) ${ }^{19}$ studied 105 (88 male and 17 female) cadavers at southern India and found the pyramidal lobe in 61 cases (58\%) and levator glandulae thyroideae in 52 (49.5\%). The results of the present study are more or less similar with the previous studies. Jackson $(1931)^{20}$ performed a histomorphometric study of the sections of the thyroid gland of men and found that the follicles increased in length and breadth with age. Thyroid tissue was also found in the pyramidal lobe. Ronald and Thomas (1961) ${ }^{21}$ described the follicles as the structural units of the gland and also stated that they may vary greatly in size and shape depending upon the degree of distension by the secreted colloid. There were no previous studies on histology of the pyramidal lobe of the thyroid gland in our country. The present study was a modest effort to collect data on pyramidal lobe and to set a standard for Bangladeshi people.

\section{Conclusion:}

The length, breadth and thickness of the pyramidal lobe may vary with age but the difference is not statistically significant. The proportion of the parenchyma increases with advancing age upto 50 years. Then it gradually decreases. Further studies with larger samples and advanced histological techniques are recommended.

\section{Ethical clearance:}

This research work was approved by the Ethical Review Committee of Dhaka Medical College, Dhaka.

\section{Acknowledgement}

We express our heartfelt gratitude to the authority of Health, Nutrition and Population sector Programme (HNPSP) of Directorate General of Health Services (DGHS) of Government of the People's Republic of Bangladesh and Dhaka Medial College for providing us the research grant.

\section{References:}

1. Moore KL, Dalley AF. Clinically oriented anatomy. $5^{\text {th }}$ ed. Philadelphia: Lippincott Williams \& Wilkins; 2006; p. 1083-7.

2. Berkovitz BK. editor. Neck and upper aerodigestive tract. In: Standring S, Ellis H, Heally JC, Johnson D, Williams A, Collins P, Wigeley C. editors. Gray's Anatomy: The anatomical basis of clinical practice. $39^{\text {th }}$ ed. Edinburgh: Elsevier Churchill Livingstone; 2005. p. 560-4.

3. Snell RS. Clinical anatomy. $7^{\text {th }}$ ed. Baltimore: Lippincott Williams \& Wilkins; 2004. p. 74548.

4. Blumberg NA. Observations on the pyramidal lobe of the thyroid gland. S Afr Med J. 1981 June; 59(26): 949-50.

5. Ross MH, Romrell LJ, Kaye GI. Histology: a text and atlas with correlated cell and molecular biology. $3^{\text {rd }}$ ed. Baltimore: Lippincott Williams \& Wilkins; 1995. p. 603-6.

6. Hamilton WJ, Mossman HW. editors. Hamilton, Boyd and Mossman's human embryology: prenatal development of form and function. $4^{\text {th }}$ ed. London: Williams \& Wilkins; 1978. p. 223-6.

7. Braun EM, Windisch G, Wolf G, Hausleitner L, Anderhuber F. The pyramidal lobe: clinical 
anatomy and its importance in thyroid surgery. Surg Radiol Anat. 2007 Feb; 29(1): 21-7.

8. Wahl R, Mah U, Kallee E. Hyperthyroidism with or without pyramidal lobe Graves' disease or disseminated autonomously functioning thyroid tissue? Clin Nucl Med 1997; 22: 4518.

9. Geraci G, Pisello F, Li Volsi F, Modica G, Sciumè $C$. The importance of pyramidal lobe in thyroid surgery. G. Chir. 2008 Nov-Dec; 29(11-12): 479-82.

10. Brown RA, Al-Moussa M, Beck JS. Histometry of normal thyroid in man. J Clin Pathol. 1986; 39: 475-82.

11. Aherne W, Dunnill MS. Quantitative aspects of placental structure. J Pathol Bacteriol. 1966; 91: 123-39.

12. Marshall CF. Variations in the form of the thyroid gland in man. J Anat Physiol. 1895; 29: 234-9.

13. Izenstark JL, Forsaith AL and Horwitz NH. The pyramidal lobe in thyroid imaging. $\mathrm{J}$ Nucl Med. 1968; 10(8): 519-24.

14. Enayetullah M. Gross and histomorphological study of the thyroid and parathyroid glands in Bangladeshi people (M.Phil.Thesis). Dhaka: University of Dhaka; 1996.
15. Begum M. Gross and histomorphological study of human postmortem thyroid gland in Bangladeshi people (M.Phil.Thesis). Dhaka: University of Dhaka; 2004.

16. Sultana SZ, Mannan S, Ahmed MS, Rahman MM, Khan MK, Khalil M. An anatomical study on pyramidal lobe of thyroid gland in Bangladeshi people. Mymensingh Med J. 2008 Jan; 17(1): 8-13.

17. Sultana SZ, Khalil M, Khan MK, Shamim R, Parveen S, Ara ZG. Morphological study of levetor glandulae thyroidea in Bangladeshi cadaver. Mymensingh Med J. 2009 July; 18(2): 179-83.

18. Lehr RP Jr. Musculus levator glandulae thyroideae: an observation. Anat Anz. 1979; 146: 494-6.

19. Ranade AV, Rai R, Pai MM, Nayak SR, Prakash, Krisnamurthy A and Narayana S. Anatomical variations of the thyroid gland: possible surgical implications. Singapore Med J. 2008; 49(9): 831-4.

20. Jackson JL. The shape and size of human thyroid follicle in health and disease. Anatomical record. 1931; 48: 220-37.

21. Ronald LC, Thomas SL. editors. Histology. $3^{\text {rd }}$ ed. Philadelphia: W B Saunders; 1961. p. 4615. 